\title{
The concept of 'touch' in the formation of the Croatian and Turkish lexicon: The example of tactile verbs
}

\author{
Ida Raffaelli and Barbara Kerovec \\ University of Zagreb, Croatia
}

\begin{abstract}
This paper explores the importance of the concept of 'touch' in the formation of the Croatian and Turkish lexicon. The main goals of the paper are 1) to investigate differences and similarities in conceptual mappings based on the concept of 'touch' in two typologically different and genetically unrelated languages by analyzing verbs referring to touch in Croatian and Turkish 2) to see to what extent the formation of tactile verbs differs with respect to lexicalization patterns in the two languages.
\end{abstract}

Keywords: the concept of 'touch', tactile verbs, lexicalization patterns, Croatian, Turkish

\section{Introduction}

The paper explores the importance of one of five sensory concepts - the concept of 'touch' - in the formation of the Croatian and Turkish lexicon. ${ }^{1}$ Previous works dealing with sensory domains in language (Williams, 1976; Viberg, 1984; Sweetser, 1990) have shown that a) concepts from one sensory domain can be used in conceptualizing concepts from other sensory domain(s), and that b) concepts from various abstract domains are frequently and regularly conceptualized on the basis of concepts from sensory domains. According to the embodiment hypothesis within the Cognitive Linguistic theoretical framework (CL), an extension of meaning from a concrete to an abstract domain is explained via conceptual metaphor (cf. Lakoff \& Johnson, 1980; Kövecses, 1986; Lakoff, 1987; Johnson, 1987; Kövecses, 2002). Conceptual metaphors involve understanding experiences from one conceptual domain in terms of experiences from another domain. Since our earliest and primary experience of the world is

\footnotetext{
A very detailed analysis of lexicalization patterns related to the vocabulary of 'taste' in Croatian and Turkish is presented in the work of Raffaelli and Kerovec (2017). The analysis of the touch vocabulary is closely related to the previous one according to the theoretical framework and the methodology used. The reason for implementing the same framework is to collect language data that could be comparable in terms of common theoretical tenets and the same analytical apparatus.
} 
achieved through sensory perception, perceptual experience often appears to be the basis for understanding other, more abstract phenomena. Therefore, it can be stated that conceptual metaphors are usually perceptually based, which could be the reason why there are some crosslinguistic regularities in the way we use such metaphors in linguistic expressions. However, some of the studies done so far have shown that, besides regularities, there are also some crosslinguistic differences in the way lexemes and lexical structures of perception vocabulary extend their meanings onto abstract domains, in spite of the fact that sense modalities are biologically common to all humans. Differences have been observed with regards to different language families and cultures. The main goals of the paper are 1) to investigate regularities and specificities in conceptual mappings based on the concept of 'touch' in two typologically and genetically different languages and 2) to see to what extent the formation of the touch vocabulary differs with respect to lexicalization patterns in the two languages. The term touch vocabulary refers to a structure of lexemes which can have very different meanings but whose roots are related primarily to the concept of 'touch'. The research in the paper is limited only to verbs. A comparative analysis of the two typologically and genetically unrelated languages, such as Croatian and Turkish, could point to differences and similarities in lexicalization processes operative in the formation of vocabularies related to the concept of 'touch'.

In the following chapters our aim is to: (i) give a brief overview of the analysis of the 'touch' domain in other linguistic approaches; (ii) present some basic theoretical and methodological tenets of the analysis, and (iii) give an analysis of the Croatian and Turkish verbs related to the concept of 'touch'. We will end the paper with some concluding remarks.

\section{The concept of 'touch' in linguistic analysis}

One of the most influential works in the field of meaning extensions of the lexemes related to perception is certainly the work of Eve Sweetser (1990) who has pointed to the intricate relation between the concept of 'touch' and the domain of 'emotion' (for instance, Celtic and Germanic show general homonymy in these two areas; a good example is Engl. feel) (Sweetser, 1990, p. 37). As one of the strongest motivating factors for this interrelatedness Sweetser notes (citing Kurath, 1921) that, as she puts it, "there is no a simple and tidy way to divide physical perception from emotions": "physical pain is bound to make the subject unhappy emotionally"; on the other hand, "physical pleasure or well-being certainly promotes a cheerful emotional state" (Sweetser, 1990, p. 44). It means that physical pain is closely related to unhappiness and vice versa, physical pleasure with happiness. The modality of touch exhibits a property that is not characteristic for other hierarchically higher modalities ${ }^{2}$, like sight and hearing. Information gathered by the modality of touch is mostly very specific, intimate and cannot be generalized. This is the reason why the modality of touch does not conceptually relate to knowledge, but mostly to emotions. Sweetser (1990, p. 44) illustrates this claim with the story of the blind men and the elephant, pointing out that the story captures in a nutshell the reason why there is no

2 Viberg (1984) presents a hierarchy of sense modalities and, accordingly, a hierarchy of the perception vocabulary. The touch modality is in the centre of the hierarchy, while sight is on the top and taste on the bottom of the hierarchy. 
conceptual mapping from touch to knowledge, which is regular and frequent for the sight vocabulary. The only expression in Croatian that relates to knowledge by using the tactile verb is ispipati situaciju (lit. 'to touch a situation all over repeatedly and thoroughly') 'to investigate the situation', while in Turkish none of the tactile verbs can have a meaning related to the domain of knowledge.

A detailed cross-linguistic analysis of meaning extensions of verbs referring to touch has been conducted by Ibarretxe-Antuñano (2006). In this research on basic/generic tactile verbs in Basque, English and Spanish, Ibarretxe-Antuñano has elaborated mappings from the domain of tactile perception onto other domains of experience in a more detailed way than Sweetser has. She has identified four basic meaning extensions of tactile verbs:

1) 'to affect (physically or metaphorically)'

e.g.: physically: Just don't touch anything in my room. ('change of location', 'change'), metaphorically: John touched Mary's heart. ('change of emotions or state')

2) 'to partake food/drink', e.g. John hardly touched the food.

3) 'to reach'

spatial end-point: $\quad$ El barco tocó puerto ayer. (lit. The ship touched the port yesterday) 'The ship arrived yesterday.'

temporal end- point: Tocan a pagar. 'It is time to pay.'

touch.3.p to pay

metaphorical end-point: He touched the high point in his career.

4) 'to deal with (superficially)'

e.g. I wouldn't touch that business.

He barely touched on the incident in his speech.

It can be seen that the first of these meaning extensions - 'to affect' - is linked to a wider domain which subsumes not only the domain of 'emotion' (as identified by Sweetsers) but some other domains as well, like 'change of location'. In addition, the domain of 'reaching' also includes several very different subdomains (spatial, temporal and metaphorical in the strict sense).

In this paper we have taken the results of Ibarretxe-Antuñano as a starting point for the analysis of conceptual mappings since the data of Croatian and Turkish tactile verbs show similar trends in meaning extensions. We particularly agree with the thesis that the domain of 'affecting' is more appropriate than just the domain of emotions since it is an overarching structure for a variety of experience domains. However, typological differences between the two languages we have dealt with required a more comprehensive analytic approach of the tactile verbs.

One of the main typological differences between Croatian and Turkish is the existence of prefixation in Croatian as one of the main word-formation processes enabling the formation of new verbs. Therefore, one of the aims of this research is to define the way prefixation - which does not exist in Turkish - can influence the formation of the lexicon. In other words, the goal is to investigate how this word-formation process is related to the lexicalization of experiences 
from different domains and what are the differences and similarities with Turkish as an agglutinative language, in which suffixation is a dominant word-formation process.

As we will show further in this paper, such an approach enables: 1) the investigation of morphological (derivational) devices used in building lexicon and influencing the change of meaning and 2) a more fine-grained classification of the meaning extensions (and conceptually related domains), 3) an insight into similarities and differences in meaning extensions driven by grammatical differences between prefixation in Croatian and agglutination in Turkish.

\section{Theoretical framework and methodology}

The model that we find suitable for pointing to differences and similarities in lexicalization of the concept of 'touch' is the model of lexicalization patterns'. The term lexicalization pattern, as used in this paper, is closely related to Talmy's (1985) notion of lexicalization patterns. ${ }^{4}$ There are, however, some differences between our approach and Talmy's. The main difference is that we define lexicalization patterns mostly with respect to the stem or root that has served as a basis for the formation of newly formed (derived) lexemes. Thus, the lexemes under investigation are morphologically and semantically related. Similar to Talmy, we believe that the analysis of lexicalization patterns consists in defining diverse lexical forms that capture the way the world is conceptualized. Thus, it is necessary to define types of lexicalization patterns that lexicalize certain concepts or conceptual mappings within a certain language or among languages. The model of lexicalization patterns defines morphological and semantic features that are similar or different for lexemes that share the same formal (stem) or conceptual basis. Therefore, it is possible to recognize conceptual and semantic extensions captured by the same or different lexicalization patterns - which is not the case in Talmy's model. Moreover, the model of lexicalization patterns (as developed by Raffaelli \& Kerovec, 2017) shares an important feature with Talmy's model: the notion of typological relevance. Some lexicalization patterns can be language specific, and some can be regular and frequent among languages, mostly within a specific language family.

The typological relevance of the model of lexicalization patterns is foremost seen in the ability of the model to define diverse strategies used in building lexicon as well as lexical forms that capture the way the world is conceptualized in genetically close or remote languages. The analysis of the language data will point to three different typological features that influence lexical structures in the two languages.

\footnotetext{
3 The model has already been implemented in the analysis of the vocabulary related to the concept of 'taste' in Croatian and Turkish. See Raffaelli and Kerovec (2017).

4 Talmy (1985, p. 57) defines lexicalization patterns as a relation between meaning and surface expressions and investigates which semantic elements are expressed by which surface elements. Semantic elements of different types can be expressed by the same type of surface element, as well as the same type of semantic element can be expressed by several different surface elements. A range of typological patterns and universal principles can be found by such an approach.
} 


\subsection{Methodology}

In the analysis that follows, verbs primarily related to the concept of 'touch' have been selected and each of them has been checked for meanings and contextual uses in Croatian and Turkish dictionaries ${ }^{5}$ and in the Croatian National Corpus (CNC), Croatian Web Corpus (HrWaC) and METU Turkish Corpus. Corpus-based data enabled to point to a regular and frequent usage of the analysed verbs. Croatian language is taken as a starting point in the analysis and Turkish vocabulary is compared with respect to lexicalization patterns established for Croatian.

In the next chapters we will try to point to:

1) the main typological differences concerning a diversity of lexicalization patterns in the two languages which influence meaning extensions;

2) the main regularities and specificities in meaning extensions (conceptual mappings) of the tactile verbs in the two languages.

\section{Croatian and Turkish verbs referring to the concept of 'touch' and their semantic extensions}

According to the corpus and dictionary-based data, in Croatian there are three, and in Turkish two main verbal roots related primarily to the concept of 'touch', which serve as a basis for the formation of tactile verbs. In Croatian these are tak, dir and pip and in Turkish dokun and değ.

\subsection{Aspect as a typologically relevant feature}

The first typological difference between Croatian and Turkish is that in Croatian the category of verbal aspect is expressed morphologically while in Turkish this is not the case. Thus, three main Croatian tactile verbs have their perfective and imperfective forms as follows:

dotaknuti, taknuti, perf./ ticati, ${ }^{6}$ imperf. 'to touch'

dodirnuti, dirnuti, perf. / dirati imperf. 'to touch'

popipati, pipnuti perf. / pipati imperf. 'to touch'

On the other hand, two main Turkish verbs related to touch do not change morphologically to express aspect (aspect is denoted by verb tenses and periphrastic constructions):

dokunmak (perf. and imperf.) 'to touch'

değmek (perf. and imperf.) 'to touch'

This is an important difference between the two languages because in Croatian the morphological change affects not only the change of aspect, but additionally, different aspectual forms have different concrete and abstract meanings, i.e. they are semantically related to

5 For the dictionaries consulted in the research see the list at the end of the paper.

6 It has to be pointed out that the aspectual pair taknuti, perf. and ticati, impf. do not share the same etyom, i.e. their origins are diverse with respect to Old Slavic lexemes. However, they have become close over time and are nowadays considered as an aspectual pair as in dotaknuti - doticati 'to touch superficially'. 
different experiential domains. For instance, the verb taknuti, perf. extends its meaning to the domain of emotions (e.g. taknuti koga u srce 'to touch someone's heart', or taknuti u živac 'to touch someone's nerve', 'to provoke') while the verb ticati, impf. is linked to the domain of 'concern' or 'relatedness' (e.g. To se tiče svakoga od vas. 'It concerns all of you / it is related to all of you'). Moreover, there is a systematic difference between taknuti and ticati. While taknuti can refer to the concrete domain of touch as well as to the domain of emotions, ticati cannot. Its only meaning is 'to concern'. The same holds for dirnuti 'to move emotionally', dirati 'to bother' (e.g. To me uopće ne dira 'It doesn't bother me at all'), and pipnuti (in negative constructions such as Nisam ni pipnula juhu/knjigu. ${ }^{7}$ in a broader meaning 'not to consume at all', 'I didn't even taste the soup / I didn't even open the book'. All the verbs, except the verb ticati, refer to the domain of touch and to one or more abstract domains. Additionally, the Croatian suffix -nu-, that appears in the verbs taknuti, pipnuti and dirnuti (all perfective verbs) carries a diminutive meaning, i.e. the meaning that refers to the activity being performed in a small quantity, superficially and at once. As pointed out by Katunar (2013: 9) there is a difference between the diminutive suffix $-n u$ - and $-k$ - as in pipkati, dirkati. Pipnuti and dirnuti are perfective forms referring to an activity that has happened superficially and rapidly only once, whereas verbs formed with the suffix $-k$-pipkati and dirkati are imperfective verbs and refer to a repeated action of touching somebody or something as in: Nježno ju je dirkao laticama cvijeta. 'He touched her gently with flower petals.' In Turkish, all these meanings of different forms of Croatian verbs can be conveyed by the same form of the verb dokunmak (except the meaning of 'concern' like in To se tiče svakoga od vas. 'It concerns all of you' which cannot be expressed by Turkish tactile verbs): Gözyaşları bana dokundu. 'Her tears touched me (emotionally).', yumurtaya bile dokunmayacak kadar vejetaryen 'vegetarian to the degree that he wouldn't even touch (consume) an egg', birinin sinirine dokunmak 'to get on one's nerves' (lit. to touch one's nerve), eğitim konusuna dokunan bir yazı 'a document related to the question of education'. The meaning extension of tactile verbs to the domain of 'bothering' or 'disturbing' can be seen in both languages, but in Turkish the verb dokunmak additionally extends its meaning to the domain of harming health, again without any morphological change: Bu hava/yemek bana dokunur. 'This weather/food harms me (harms my health)' (lit. 'This weather/food touches me.'). As far as repeated action is concerned, in Turkish it can be expressed by a duplicated form of the converb $-(y) A$ signaling the intensity of an action (e.g. karanlikta dokuna dokuna 'tapping in the dark'). The diminutive meaning is again not expressed morphologically, but lexically, either by 1) an adverb signaling diminutive meaning such as hafif̧̧e 'gently'+ dokunmak 'gently touch', or 2) the verb değmek 'to touch (slightly)'. The verb değmek is, in comparison to the verb dokunmak, more likely to be used in contexts where the meaning of superficial contact should be conveyed: Kapıdan bir an birbirimize değerek girdik. 'We entered through the door touching one another for a moment'.

\footnotetext{
It has been suggested (Barcelona, p.c.) that instead of having the meaning 'to partake of food or drink', which is too specific, it would be better to propose a more general meaning like 'to partake of something'. While Ibarretxe-Antuñano thinks that it should be reserved only to food and drink, our example shows that it can be extended to other domains as well.
} 
Turkish tactile verbs değmek and dokunmak extend their meanings to the domain of 'reaching' more productively than Croatian tactile verbs in spite of the fact that they do not change morphologically: e.g. Mektup elime değdi. 'I received the letter' (lit. 'The letter touched my hand'), Kurşun hedefe değdi. 'The bullet hit the target' (lit. 'The bullet touched the target'). The meaning of 'reaching' of the verb değmek extends additionally to the abstract domain of 'value', in the sense of reaching the price of something, e.g. Ömrümün üç günüü̈çÿ̈z bin liraya değer. 'Three days of my life are worth three hundered lira.', lit. 'Three days of my life touch (reach) three hundered lira.'. The fact that we must reach something in order to touch it triggered a semantic extension of the verb dokunmak too, but its extended meaning is related more to the abstract domain of 'affecting', as in Onun benim gibi çok kişiye yardımı dokundu. 'He helped many people like me', lit. 'His help touched (reached) many people like me', Felsefenin bana çok faydası dokundu. 'I have benefited a lot from philosophy.', lit. 'A lot of philosophy's benefit touched (reached) me.'

\subsection{Prefixation as a typologically relevant feature}

The second important typological difference between Croatian and Turkish is prefixation which exists in Croatian but not in Turkish as an agglutinative language. Prefixes in Croatian can trigger divers meaning changes. There is a significant difference between taknuti vs. dotaknuti and dirnuti vs. dodirnuti. Dodirnuti and dotaknuti lexicalize a less superficial activity, with an implication that the activity has lasted for a certain period of time. This is especially visible in metaphorical usage, as in: Nakon toga njihov je odnos dotaknuo dno. 'After that their relationship has reached the bottom'. ${ }^{8}$ In this expression, a prior event to the one lexicalized by the expression is implicated. In other words, something happened before and caused the final stage of their relationship.

Another lexical refinement in the physical domain can be observed for the verb taknuti: different prefixes contribute to the modification of spatial meanings, which can be considered as meaning extensions from the domain of touch to the spatial domain in the strict sense:

nataknuti 'to put/slip/fix on'

zataknuti 'to hook on', 'to stick/push/thrust/tuck in'

utaknuti 'to push/thrust/fix/wedge in(to)', 'plug up, socket'

Such a lexical refinement of the physical features of the touch modality in Croatian cannot be expressed by Turkish tactile verbs.

Furthermore, some prefixed forms of Croatian tactile verbs convey metaphorical, abstract meanings which cannot be conveyed by Turkish tactile verbs. One of the verbs which is regularly used in meanings related to abstract domains is the verb dotaknuti. The verb dotaknuti is very frequently used in the meaning 'to gently affect' or 'to mention' as in: To je zemlja koju je turizam tek dotaknuo. 'This is a country that has only recently been affected/touched by tourism.' or U svom je govoru dotakla mnoga aktualna pitanja. 'She mentioned / touched upon

8 This is the only expression in which the Croatian tactile verb is used in the meaning of 'reaching'. 
many current issues in her speech.'. The verb potaknuti has exclusively metaphorical meaning 'to stimulate', 'to encourage', 'to animate' and istaknuti means 'to stress/emphasize', 'to point out', 'to bring into prominence'. As can be seen, dotaknuti, potaknuti and istaknuti share the same verbal stem, i.e. they are derived from the verb taknuti. However, they differ with respect to their semantic structures. Dotaknuti can refer to touch as well as to abstract domain of 'affecting' and 'mentioning' whereas potaknuti and istaknuti cannot refer to touch. They convey exclusively abstract meanings. It must be pointed out that Turkish tactile verbs cannot express the meanings 'to stress/emphasize'and 'to stimulate', 'to encourage', 'to animate'. As for the meaning 'to mention', it can be conveyed by the reflexive form of the verb değmek, which will be analysed in the subchapter "Suffixation as a typologically relevant feature".

\subsection{Prepositions as a typologically relevant feature}

The third typological difference is related to prepositions which do not exist in Turkish. In Croatian different preposition when combined with a tactile verb influence the change of its meaning, e.g. with the preposition po 'along/over' the verb dirnuti has exclusively concrete meaning (dirnuti po ramenu 'touch (upon) one's shoulder') while with the preposition $u$ 'in' conveys the meaning related to emotions (dirnuti u srce 'to touch one's heart'). It is interesting that the preposition $u$ 'in', when combined with the verb taknuti, represents a construction ${ }^{9}-$ taknuti $u$ - which conveys a very specific meaning 'to affect something or somebody deeply'. Namely, taknuti as a diminutive verb that refers to a superficial and brief action, when combined with the preposition $u$ as in taknuti $u$ denotes an abstract event that has a severe and profound impact on someone or something: e.g. taknuti $u$ dušu 'to touch someone's soul', taknuti u živac 'to irritate someone', taknuti u tradicijske vrijednosti 'to touch traditional values'.

Although Turkish postpositions can in some aspects be compared to Croatian prepositions, they do not combine with tactile verbs; Turkish verbs dokunmak and değmek always combine with the same case, no matter whether a meaning is physical (concrete) or metaphorical (abstract), and that case is dative, morphologically denoted by the suffix $-(y) A$, e.g.:

omzuna dokunmak 'to touch (upon) one's shoulder'(physical touch)

kalbine dokunmak 'to touch one's heart' (emotions)

Elim onunkine değdi. 'My hand slightly touched his (hand)' (physical touch)

Onun için her şeyi feda etmeye değer 'For her it's worth to sacrify everything' (value)

\subsection{Suffixation as a typologically relevant feature}

The fourth typological difference is related to factitive/causative and reciprocal categories which are in Turkish expressed by different suffixes. These suffixes, when added to the root değ(referring primarily to the concept of touch) trigger a semantic extension to the domain of

9 The role of governed prepositions in the formation of the V PP constructions in building lexicon is comprehensively analysed and described in Katunar (2015). 
'affecting', but to a subdomain which cannot be lexicalized by Croatian tactile verbs, and that is the subdomain of 'change' (in the strict sense):

değmek 'to touch' $\rightarrow$ değ-iş-mek 'to change (intrans.)' $\rightarrow$ değ-iş-tir-mek 'to change (trans.)'

These meanings can be subsumed under the broader domain of 'affecting'. The motivation for this meaning extension could be explained by the fact that in order to change something, we must touch it.

On the other hand, when the reflexive suffix -in is added to the same root $d e \breve{g}_{-}$, it changes its meaning in a similar way the Croatian reflexive pronoun se does in combination with the prefixed form of the diminutive verb taknuti:

değ-in-mek vs. dotaknuti se 'to deal with / to comment on / to talk about / to mention'

e.g. Tur. kimlik konusuna değinmek vs. Cro. dotaknuti se teme identiteta 'to mention / to talk about the matter of identity'

\section{Discussion}

All the data analyzed so far show some semantic specificities and regularities between Croatian and Turkish with respect to diverse lexicalization patterns. Finally, it is necessary to compare differences and similarities between Croatian and Turkish in lexicalization of conceptual domains and to shed light on some conceptual subdomains within the domains already defined by Ibarretxe-Antuñano (2006). The table (1) below shows that in this respect overlaps between the two languages are only partial. Even in the physical domain of 'touching', Croatian shows a more fine-grained lexicalization of diverse physical activities. For instance:

1) The verbs taknuti, pipnuti and dirnuti lexicalize a punctual event - something that happened very rapidly, superficially and once. Both verbs are derived via a diminutive suffix - $n u$ - referring to the activity that is performed in a small quantity or intensity. On the other hand, verbs pipkati, dirkati are also diminutive verbs, formed with the suffix $-k$-, but referring to a repeated, successive action. In Turkish such a difference cannot be lexicalized by a morphological change of a verb.

2) The imperfective verb pipati 'touch, palpate', which does not have its simple lexical equivalent in Turkish, expresses a durative activity. It differs from dirati (also imperfective form) in the sense that it lexicalizes (very often) a chain of tactile movements that we perform in order to find something (Pipala sam po mraku zidove da nadem zvono na vratima 'I've been touching the walls in the dark to find the doorbell'). In the fourth row of the table it can be seen that the meaning 'to find something by touching' in Croatian (but not in Turkish) extends to the domain of knowledge: the prefixed verb ispipati conveys the abstract meaning 'to investigate/inquire' with the result of revealing something, as in already mentioned example ispipati situaciju 'to investigate a situation'.

3) Different spatial meanings of fixing something on or in(to) and which are conveyed by prefixed forms of the verb taknuti (nataknuti, zataknuti, utaknuti) cannot be lexicalized by Turkish tactile verbs. 
4) The meaning of 'physically reaching something' can be expressed by a tactile verb only in Turkish (Mektup elime değdi lit. 'the letter touched my hand' I received a letter). Additionally, Turkish verbs değmek and dokunmak are more productive when meaning extensions via the domain of 'reaching' are concerned.

5) In the fifth row of the table it can be seen that the domain of 'affecting' includes several different, but conceptually related subdomains which are differently lexicalized in the two languages. The subdomains of 'affecting emotionally' and 'disturbing', 'bothering' overlap, but in Croatian the verbs change morphologically while in Turkish they do not (and this tendency can be observed in Turkish in all the domains lexicalized by tactile verbs, which can be seen in the last right column of the table). The meanings of 'disturbing health' and 'change' are lexicalized only in Turkish, while the meaning of animating, initiating or encouraging only in Croatian.

6) The subdomain of 'dealing with' or 'concerning' is lexicalized in both languages, while the meanings 'to emphasize' (Croatian) and 'to be worth' (Turkish) are not.

Table 1: Lexicalization of diverse domains and subdomains

\begin{tabular}{|c|c|c|c|}
\hline & & CROATIAN & TURKISH \\
\hline PHYSICAL T & $\mathrm{OUCH}$ & taknuti, dirnuti - punctual, superficial & $\mathrm{DAT}+$ değmek \\
\hline & & pipati - chain of tactile movements & $\mathrm{DAT}+$ dokunmak \\
\hline FIXING $(\mathrm{ON} /$ & IN) & nataknuti vs. zataknuti vs. utaknuti & $\mathbf{x}$ \\
\hline REACHING ( & $\rightarrow$ Tur. affecting) & $\begin{array}{l}\text { dotaknuti dno 'to reach the bottom' } \\
\text { (abstract) }\end{array}$ & $\mathrm{DAT}+$ değmek \\
\hline FINDING $(\rightarrow$ & knowledge) & napipati 'to feel / find by touching' & $\mathbf{X}$ \\
\hline & & ispipati 'to investigate/inquire' (abstract) & \\
\hline AFFECTING & Emotions & dirati $\boldsymbol{u}$, dirnuti $\boldsymbol{u}$ & $\mathrm{DAT}+$ dokunmak \\
\hline & Disturbing / & dirati (+ACC) & $\mathrm{DAT}+$ dokunmak \\
\hline & bothering & zadirkivati 'to tease' (+ACC) & \\
\hline & Disturbing health & $\mathbf{X}$ & $\mathrm{DAT}+$ dokunmak \\
\hline & Benefiting & $\mathbf{X}$ & $\mathrm{DAT}+$ dokunmak \\
\hline & Initiate / encourage & Potaknuti & $\mathbf{X}$ \\
\hline & Change (general) & $\mathbf{X}$ & değişmek (intrans.) \\
\hline & & & değiştirmek (trans.) \\
\hline DEALING W & TH (concern) & ticatise & $\mathrm{DAT}+$ dokunmak \\
\hline & & dotaknuti (se) & $\mathrm{DAT}+$ değinmek \\
\hline EMPHASIZII & JG / POINTING OUT & istaknuti (se) & $\mathbf{X}$ \\
\hline VALUE (reacl & ing the price) & $\mathbf{X}$ & $\mathrm{DAT}+d e \breve{g m} m e k$ \\
\hline
\end{tabular}

\section{Conclusion}

A contrastive analysis of two languages such as Croatian and Turkish showed that there is a need for introducing a more comprehensive analytic approach to tactile verbs, as to any other perception vocabulary. Turkish and Croatian tactile verbs show the potential for a more finegrained classification of conceptually related domains. As our analysis shows, Croatian verbs vary in lexicalization already in the domain of a physical sense modality due to prefixation and suffixation. Moreover, the model of lexicalization patterns points to diverse grammatical 
devices that encode a certain meaning, as in the examples of V PP constructions - taknuti po, taknuti $u$ and others. These constructions where different prepositions are used differ significantly in meanings. The construction taknuti po refers to the physical, whereas taknuti $u$ is related to the domain of emotions.

Defining lexicalization patterns provided an in-depth semantic analysis of how certain conceptual and semantic structures are captured and conveyed by diverse grammatical devices. This kind of approach enables a more fine-grained definition of conceptual domains and subdomains that are lexicalized via morphologically and semantically close verbs in the two typologically different languages. As shown in our analysis, differences between the two languages can be seen only if subdomains are observed - as illustrated in the Table 1, Croatian and Turkish show very little overlaps on the level of subdomains. The defined domains and subdomains represent encyclopedic knowledge that is encoded in different lexical forms in the two languages.

Finally, it has to be noted that it was not possible to give an overall fully exhaustive analysis of the lexicalization patterns related to tactile verbs in the two languages due to their complexity. However, we believe that the main similarities and differences between the two languages have been pointed out. It can be concluded that the model of lexicalization patterns enables to capture typological regularities as well as specificities with respect to the diversity of grammatical devices languages use to encode certain meanings.

\section{References}

Ibarretxe-Antuñano, I. (2006). Cross-linguistic polysemy in tactile verbs. In June Luchjenbroers (Ed.), Cognitive Linguistics Investigations: Across languages, fields and philosophical boundaries (Human Cognitive Processing 15) (pp. 235-253). Amsterdam, Philadelphia: John Benjamins.

Johnson, M. (1987). The Body in the Mind. The Bodily Basis of Meaning, Imagination, and Reason. Chicago/London: The University of Chicago Press.

Katunar, D. (2013). Diminutives in Action: A acognitive account of diminutive verbs and their suffixes in Croatian. Suvremena lingvistika, 75, 1-24.

Katunar, D. (2015). Ustroj leksikona u konstrukcijskoj gramatici - primjer prijedloga u hrvatskom jeziku (Doctoral dissertation). Zagreb.

Kövecses, Z. (1986). Metaphors of Anger, Pride, and Love: A Lexical Approach to the Structure of Concepts. Amsterdam, Philadelphia: John Benjamins.

Kövecses, Z. (2002). Metaphor: A Practical Introduction. New York: Oxford University Press.

Lakoff, G. (1987). Women, Fire, and Dangerous Things: What Categories Reveal about the Mind. Chicago: The University of Chicago Press.

Lakoff, G., \& Johnson, M. (1980). Metaphors We Live By. Chicago: University of Chicago Press.

Raffaelli, I. (2017). Conventionalized patterns of colour naming in Croatian. In Cergol Kovačević, K., \& Udier, S. L. (Eds.), Applied Linguistics Research and Methodology. Proceedings from the 2015 CALS conference (pp. 171186). Franfurt am Main/Bern/Bruxelles: Peter Lang Verlag.

Raffaelli, I., \& Kerovec, B. (2017). The concept of 'taste' in formation of Croatian and Turkish lexicon: A contrastive analysis. Suvremena lingvistika, 83, 21-48.

Sweetser, E. (1990). From Etymology to Pragmatics. Metaphorical and Cultural Aspects of Semantics. Cambridge: Cambridge University Press.

Viberg, Å. (1984). The verbs of perception: A typological study. In Butterworth, B., Comrie, B., \& Dahl, O. (Eds.), Explanations for language universals (pp. 123-162). Berlin: Mouton de Gruyter.

Williams, J. M. (1976). Synaesthetic Adjectives: A possible law of semantic change. Language, 52 (2), 461-478. 


\section{Dictionaries}

Damjanović, S. (2004). Mali staroslavensko hrvatski rječnik. Zagreb: Matica hrvatska.

Đinđić, S., Teodosijević, M., \& Tanasković, D. (1997). Türkçe-Sirpça Sözlük. Ankara: Türk Dil Kurumu.

Hrvatski enciklopedijski rječnik. (2002). Zagreb: Novi liber

http://www.nisanyansozluk.com/

Püsküllüoğlu, A. (2005). Arkadaş Türkçe Sözlüğü. Ankara: Arkadaş Yayınevi.

http://tureng.com/

Türkçe Sözlük. (1983). Ankara: Türk Dil Kurumu Yayınları. 